\title{
Extent and ecological importance of escape through spawning in sea-cages for Atlantic cod
}

\author{
Ingebrigt Uglem ${ }^{1, *}$, Øyvind Knutsen ${ }^{2}$, Olav Sigurd Kjesbu ${ }^{3}$, Øyvind J. Hansen ${ }^{4}$, \\ Jarle Mork ${ }^{5}$, Pål Arne Bjørn ${ }^{3,4}$, Rebekka Varne ${ }^{5}$, Rune Nilsen ${ }^{3,4}$, Ingrid Ellingsen ${ }^{2}$, \\ Tim Dempster ${ }^{6,7}$
}

\author{
${ }^{1}$ Norwegian Institute of Nature Research, Tungasletta 2, 7485 Trondheim, Norway \\ ${ }^{2}$ SINTEF Fisheries and Aquaculture, PO Box 4762 Sluppen, 7465 Trondheim, Norway \\ ${ }^{3}$ Institute of Marine Research, PO Box 1870 Nordnes, 5817 Bergen, Norway \\ ${ }^{4}$ NOFIMA Marin, Muninbakken 9-13, PO Box 6122, 9291 Tromsø, Norway \\ ${ }^{5}$ Trondheim Biological Station, Department of Biology, Norwegian University of Science and Technology, 7491 Trondheim, \\ Norway \\ ${ }^{6}$ Sustainable Aquaculture Laboratory - Temperate and Tropical (SALTT), Department of Zoology, University of Melbourne, \\ 3010 Victoria, Australia \\ ${ }^{7}$ Centre for Research-based Innovation in Aquaculture Technology (CREATE), SINTEF Fisheries and Aquaculture, \\ PO Box 4762 Sluppen, 7465 Trondheim, Norway
}

\begin{abstract}
The culture of certain fish species to sizes at which they can reproduce has led to the escape of fertilised eggs or 'escape through spawning'. To investigate the extent and ecological importance of spawning in sea-cages for Atlantic cod Gadus morhua (L.), we (1) evaluated the extent, frequency and timing of spawning in cod culture; (2) analysed the quality of eggs released from farms in terms of variation in fatty acids; (3) modelled the distribution of eggs and larvae from a commercial cod culture site; and (4) predicted the post-escape survival of eggs through summarizing existing knowledge on survival rates of different life stages. Collectively, our results indicate that cod farming has the potential to produce large amounts of eggs and larvae through spawning in cages, with numbers of eggs spawned being 4 to 5 times higher in the second than in the first year. Our scenarios suggest that a typical sea-cage with 60000 fish may produce 1.4 to 21 tons of $3 \mathrm{yr}$ old first generation farmed cod through spawning in sea-cages. The quality of escaped eggs and larvae is likely to be sufficient for larvae to survive until the first feeding, while survival until adulthood, though difficult to predict, may be high under favourable conditions. Simulations indicate that eggs and larvae from farms may mix with those of wild fish during the spawning season, and thus experience comparable larval environments. However, several implementable management measures exist that will diminish the extent of egg escape in future cod farming.
\end{abstract}

KEY WORDS: Atlantic cod $\cdot$ Gadus morhua $\cdot$ Aquaculture $\cdot$ Escape $\cdot$ Spawning in farms

Resale or republication not permitted without written consent of the publisher

\section{INTRODUCTION}

As the demand for protein increases to support a growing global human population, the production of fish in sea-cage aquaculture systems has expanded. While modern, industrial sea-cage aquaculture has been built around salmonids, which do not spawn in sea-cages, the culture of fish species that are marine, pelagic broadcast spawners and that may reproduce within sea-cages has recently increased. These include Atlantic cod Gadus morhua (Jørstad et al. 2008) and sea bream Sparus aurata (Dimitriou et al. 2007). While the extent of escapes of adult fish is relatively well documented in some countries (e.g. 
Jensen et al. 2010) and the potential for negative ecological and/or genetic consequences to occur through escape of adult farmed fish is considered to be important (Bekkevold et al. 2006), knowledge of the extent and ecological effects of 'escape through spawning' by active reproduction within sea-cages by fish is sparse (Jørstad et al. 2008, van der Meeren et al. 2012).

In Atlantic cod farms, some fish mature during the first year of culture, while the majority mature during the second year (Svåsand et al. 1996, Hansen et al. 2001, Karlsen et al. 2006, Taranger et al. 2006, 2010). Consequently, almost the entire culture stock in any particular farm has the potential to spawn in seacages. Larvae from genetically marked farmed cod that spawned in a sea-cage have been found up to $8 \mathrm{~km}$ from an experimental farm during the natural spawning season of cod (Jørstad et al. 2008). Preliminary results also indicate that offspring from spawning in the cages survive until reproductive age (van der Meeren et al. 2012). If spawning occurs within commercial cod farms where numbers of animals are far greater, the contribution of 'escaped' larvae to cod recruitment within a particular fjord or area may be substantial. Thus, it is not unlikely that cod farming could result in genetic changes in wild cod populations, as occurs for Atlantic salmon (Naylor et al. 2005, Hindar et al. 2006, Skaala et al. 2006, Ferguson et al. 2007), but not only through the escape of farmed fish from sea-cages.

The extent and effect of spawning within commercial sea-cages is largely unknown, even though it is unquestionable that farmed cod have the potential for producing large numbers of 'escaped' eggs and larvae (van der Meeren et al. 2012). The effects of spawning in sea-cages will depend not only on the numbers of eggs and larvae that escape, but also on their quality and survival, which are influenced by both innate and environmental factors such as broodstock nutrition, timing of spawning, and dispersal routes following spawning (Kjørsvik et al. 1990). Further, the ecological effect of this type of escape will depend on the degree to which local adaptations exist in wild cod stocks, in the same way as is assumed to be the case for wild salmonids (e.g. Glover et al. 2012).

We evaluated the extent and ecological importance of escape through spawning in sea-cages for Atlantic cod by (1) evaluating the extent, frequency and timing of spawning in commercial cod culture; (2) analysing the quality of eggs released from farms using fatty acid profiles as proxy indicators; (3) modelling the distribution of eggs and larvae from a com- mercial cod culture site; and (4) predicting the postescape survival of eggs through summarizing existing knowledge on survival rates of different life stages. Finally, we evaluated the need and possibility for implementing mitigative strategies for reducing or preventing escape of eggs.

\section{MATERIALS AND METHODS}

\section{Extent, frequency and timing of spawning of Atlantic cod}

Fish were sampled from 7 farms distributed from western to northern Norway (Fig. 1), prior to or during the spawning season of wild cod, from late 2009 to early 2010 and February and March 2011. Fish that had been in sea-cages for $\sim 1$ and 2 yr were sampled from 5 (Røsnes, Lyngen, Gildeskål, Frøya and Austevoll) and 4 (Ytterøya, Røsnes, Lyngen and Tysfjord) farms, respectively. The samples were used to determine sex ratio, reproductive status (see below for assessment), gonad size, fecundity and timing of spawning. Morphometric measures included total

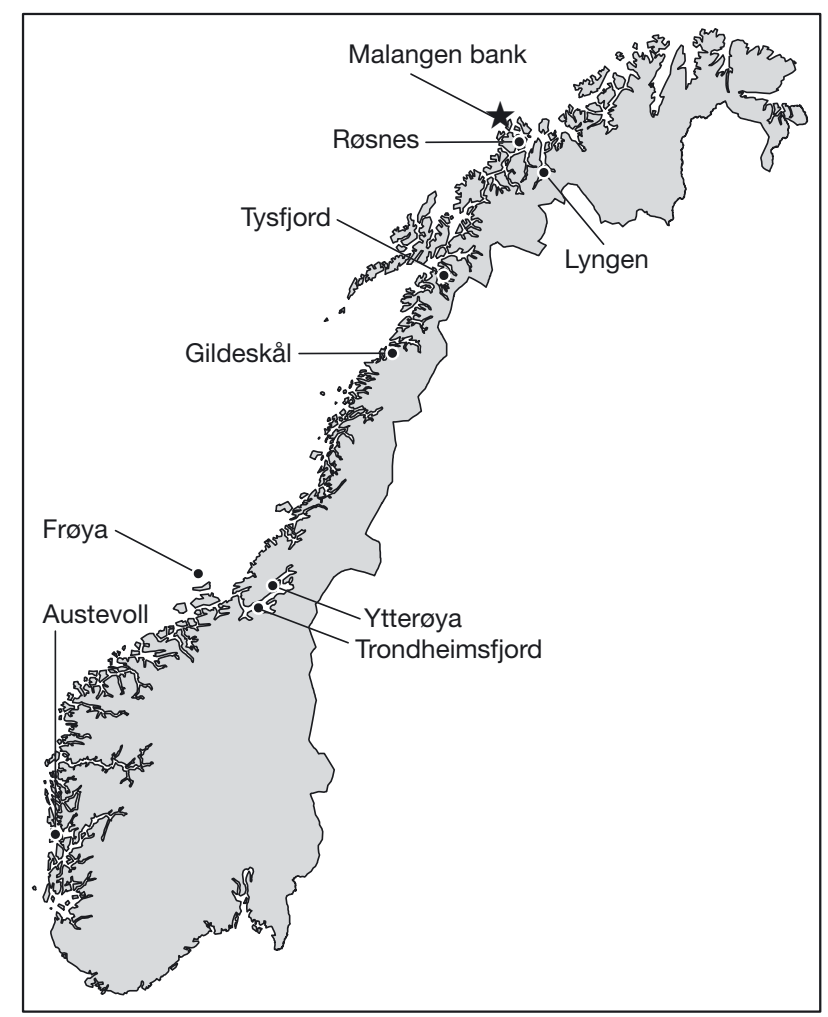

Fig. 1. Locations in Norway where Atlantic cod Gadus morhua were farmed (black circles) and location of capture of wild fish for fatty acid analysis (black star) 
Table 1. Gadus morhua. Summary of morphometric data (means \pm SD) of 2 yr old female Atlantic cod from 3 farms used for fecundity analyses. Only females with vitellogenic oocytes were used in the fecundity analyses and statistical analyses were thus performed only for these females. Different superscript letters: differences among farms, same letters $=$ no difference (1-way ANOVA with Tukey's post hoc tests, $\mathrm{df}=2, \mathrm{p}<0.05$ )

\begin{tabular}{|llrccccc|}
\hline Farm & Egg stage & $\mathrm{N}$ & $\begin{array}{c}\text { Total } \\
\text { length }(\mathrm{cm})\end{array}$ & Weight $(\mathrm{g})$ & Fulton's $K$ & $\begin{array}{c}\text { Ovary } \\
\text { weight }(\mathrm{g})\end{array}$ \\
\hline Røsnes & Vitellogenic & 31 & $58.3 \pm 3.8^{\mathrm{a}}$ & $2961 \pm 366^{\mathrm{a}}$ & $1.50 \pm 0.21^{\mathrm{a}}$ & $420.3 \pm 118.5^{\mathrm{a}}$ & $16.9 \pm 5.5^{\mathrm{a}}$ \\
Tysfjord & Vitellogenic & 22 & $57.3 \pm 3.1^{\mathrm{a}}$ & $2635 \pm 410^{\mathrm{b}}$ & $1.39 \pm 0.10^{\mathrm{b}}$ & $346.5 \pm 99.9^{\mathrm{a}}$ & $15.2 \pm 4.0^{\mathrm{a}}$ \\
& Hydrated & 4 & $57.5 \pm 2.9$ & $2614 \pm 208$ & $1.40 \pm 0.29$ & $489.5 \pm 201.0$ & $23.5 \pm 10.1$ \\
& Previtellogenic & 6 & $59.6 \pm 3.1$ & $2535 \pm 341^{\mathrm{c}}$ & $1.19 \pm 0.05$ & $66.7 \pm 30.5$ & $2.7 \pm 1.1$ \\
& Vitellogenic & 17 & $57.1 \pm 4.6^{\mathrm{a}}$ & $2306 \pm 536$ & $1.22 \pm 0.04^{\mathrm{c}}$ & $439.7 \pm 202.6^{\mathrm{a}}$ & $29.7 \pm 32.1^{\mathrm{a}}$ \\
& Hydrated & 3 & $54.2 \pm 1.9$ & $1910 \pm 211$ & $1.20 \pm 0.01$ & $582.3 \pm 175.2$ & $47.4 \pm 23.0$ \\
& Spawned & 3 & $56.2 \pm 5.7$ & $2189 \pm 737$ & $1.20 \pm 0.02$ & $316.3 \pm 221.6$ & $15.9 \pm 7.4$ \\
\hline
\end{tabular}

length, whole body weight and gonad weight. Standard Fulton condition index $[K=$ (body weight $/$ body length $\left.\left.{ }^{3}\right) \times 100\right]$ and gonadosomatic index [GSI = (gonad weight / total body weight) $\times 100$ ] were calculated and a maturation index (values 1 to 4 , with undeveloped gonads $=1$ and ripe gonads $=4$, while values 2 and 3 represented intermediate stages) recorded based on visual examination of gonad size and appearance.

Fecundity and hatching time was examined for $2 \mathrm{yr}$ old fish from 3 farms following the methods outlined in Thorsen \& Kjesbu (2001) and Kjesbu et al. (2010) (Table 1). In short, fecundity and spawning time was determined by collecting ovarian tissue that was fixed in $3.6 \%$ phosphate-buffered formaldehyde. Automated image analysis (ImageJ, available at: http:// rsb.info.nih.gov/ij) was subsequently used for measuring oocyte diameter for oocytes being $>200 \mu \mathrm{m}$. Of the 200 normal (vitellogenic) oocytes measured per sample, the largest $10 \%$ were defined as the leading cohort (LC) and the corresponding mean oocyte diameter used to predict time of start of spawning (calendar day) according to Kjesbu et al. (2010). Individual potential fecundity (i.e. standing stock of oocytes, $F_{\mathrm{p}}$ ) was determined from oocyte packing density (number of oocytes $\mathrm{g}^{-1}$ ), estimated from the mean diameter of all 200 oocytes measured in each sample, multiplied by whole ovary weight (Thorsen \& Kjesbu 2001). As $F_{\mathrm{p}}$ decreases throughout gonadal development due to atresia (Kjesbu et al. 2010), the standing stock of oocytes immediately before spawning would be lower than the $F_{\mathrm{p}}$ calculated from samples collected at various points in time prior to spawning. To adjust for atresia a linear regression between calculated $F_{\mathrm{p}}$ and LC $\left(F_{\mathrm{p}}=-8676 \mathrm{LC}+\right.$ $10000000, \mathrm{r}^{2}=0.28$ ) was used to estimate the standing stock of oocytes (oocytes at spawning $=F_{\mathrm{p}}-$
Table 2. Gadus morhua. Overview of Atlantic cod females (means $\pm \mathrm{SD}$ ) used for analyses of fatty acids in stripped eggs

\begin{tabular}{|lcccc|}
\hline Location & N & Date & $\begin{array}{c}\text { Total length } \\
(\mathrm{mm})\end{array}$ & $\begin{array}{c}\text { Weight } \\
(\mathrm{g})\end{array}$ \\
\hline Røsnes farm & 14 & 15 Mar 2010 & $568 \pm 53$ & $2705 \pm 632$ \\
Lyngen farm & 15 & 25 Mar 2010 & $516 \pm 21$ & $1858 \pm 227$ \\
Malangen wild & 15 & 23 Mar 2010 & $795 \pm 80$ & $4483 \pm 1422$ \\
\hline
\end{tabular}

[(800 - LC) $\times$ 8676]) for an assumed average LC oocyte diameter at spawning $(800 \mu \mathrm{m})$. Realised fecundity (i.e. the mean number of eggs spawned of the potential fecundity as recorded immediately before spawning, $F_{\mathrm{R}}$ ) was then predicted using data on actual proportions of eggs spawned by farmed cod of the same size and condition as examined in the present study (Kjesbu et al. 1991).

\section{Evaluation of egg quality of farmed and wild Atlantic cod}

Variation in lipids and fatty acid compositions may be used as indicators of egg and larval quality and viability in teleost fish, including Atlantic cod (e.g. Sargent et al. 1995, Pickova et al. 1997, Salze et al. 2005, Fuiman \& Ojanguren 2011, Lanes et al. 2012). Thus variation in fatty acid profiles were analysed for eggs from cod females sampled from 2 farms in northern Norway (Fig. 1, Table 2) during March 2010. Simultaneously, wild females were sampled from Malangen bank, a well-known spawning area outside Tromsø (Fig. 1, Table 2), located $\sim 80 \mathrm{~km}$ away from the nearest farm to minimize the risk of sampling escaped farm cod. Escapees can usually be 


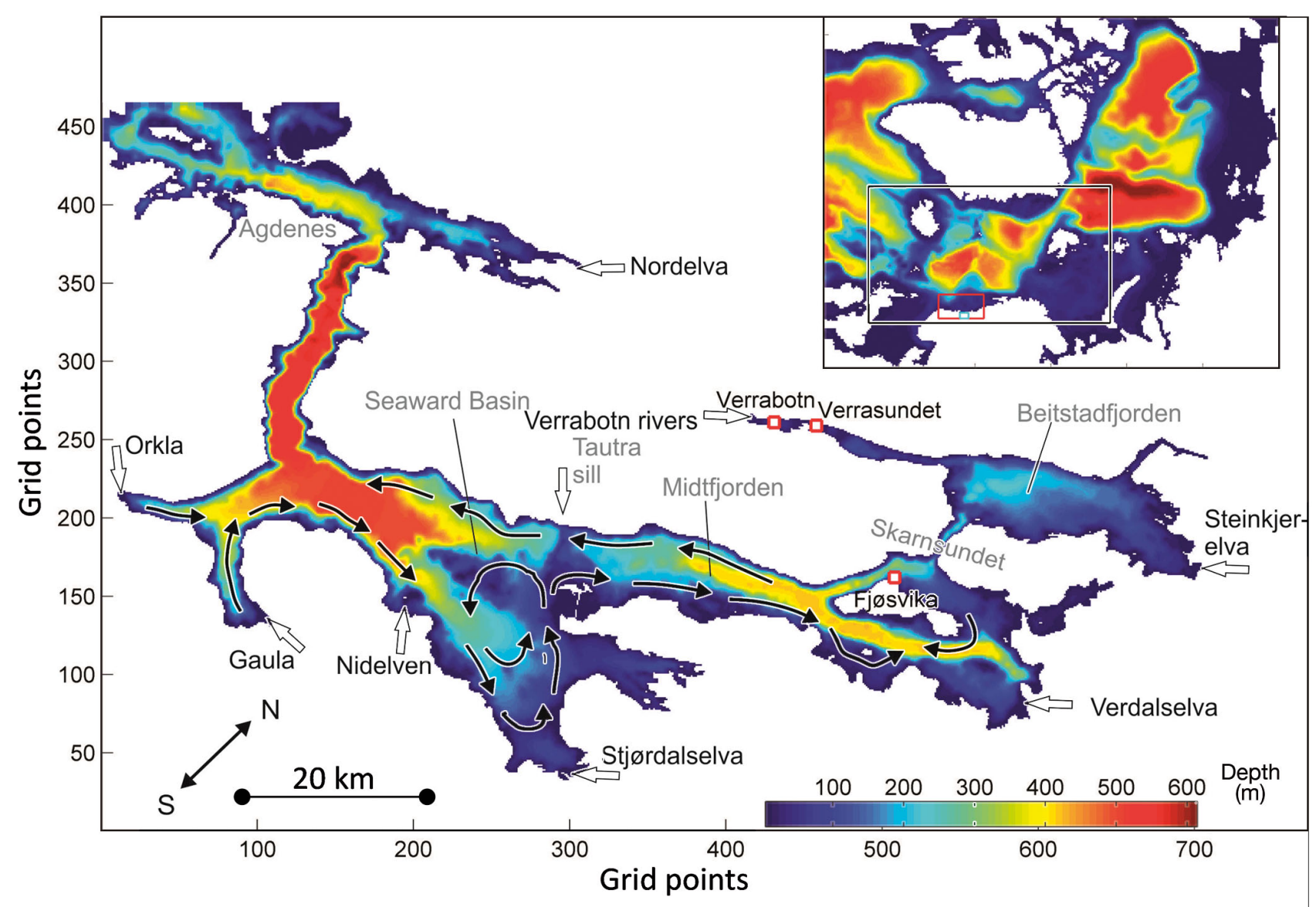

Fig. 2. Trondheimsfjorden model area. Colour scaling: depth in $\mathrm{m}$ (red: $\sim 600 \mathrm{~m}$ to blue: shallow). Red squares: release sites for Atlantic cod Gadus morhua eggs, where Verrabotn and Verrasundet are natural spawning grounds, and Fjøsvika (at Ytterøya) is the fish farm. Arrows: position of rivers and the Tautra Sill. River names are in black and other names in grey. Upper right corner inset: nesting system of the model, where larger inset generates input to the one inside (i.e. black rectangle to inside of red rectangle, to cyan rectangle which is the model area of Trondheimsfjorden)

separated from wild fish by morphology (Uglem et al. 2011). None of the wild cod examined in the current study exhibited traits that regularly are found in farmed cod (e.g. deformed mouth, worn dorsal fins or neck deformities). To be certain that wild cod were analysed, fish with even minor signs of one of these morphological deformities/traits commonly seen in escaped farmed cod were not sampled.

Only ripe females (i.e. females with running eggs) were used. Eggs were sampled by applying a gentle pressure on the abdomen. The eggs ( 5 to $10 \mathrm{~g}$ ) were stored at $-80^{\circ} \mathrm{C}$ from sampling until analysis. The storage vials were flushed with nitrogen to avoid oxidation of samples before analysis.

Fatty acids were measured with a capillary gas chromatograph (Perkin Elmer, Autosystem XL) according to Kjørsvik et al. (2009). Duplicates of each sample were analysed and mean values were used in subsequent analyses.

\section{Dispersal of Atlantic cod eggs from farms}

To evaluate if escaped cod eggs and larvae mix with those of wild cod, we used a hydrodynamic model that simulated egg and larval drift from 2 spawning areas for wild fish and from a cod farm in Trondheimsfjorden. A 3D coupled numerical model system (SINMOD) was used to simulate the currents in the area of interest and a large scale model $(20 \mathrm{~km})$ covering the Arctic Ocean, the Nordic Seas and part of the Atlantic Ocean provided boundary conditions for a model with a resolution of $4 \mathrm{~km}$. This model provided in turn boundary conditions for the shelf model with resolution of $800 \mathrm{~m}$. This nesting technique was extended further to $160 \mathrm{~m}$ resolution (Fig. 2). Hydrodynamic variables (velocities, temperature and salinity) were imposed from the coarser model into the model with higher resolution through the open boundaries according to Slagstad \& McClimans (2005). 
Trondheimsfjorden consists of 3 main basins: Seaward Basin, Midtfjorden and Beitstadfjorden (Fig. 2). The initial field was interpolated from the larger $800 \mathrm{~m}$ model that calculated the boundary conditions. This smooth initial field had some ice in the fjord, so we ran a spin-up period of $>2$ mo (January to March 2009) to remove ice and obtain more realistic structures of the hydrography. The buoyancy of cod eggs is relatively independent of normally encountered temperature ranges due to thermal expansion in the egg being nearly equal to that of sea water (Sundnes et al. 1965), and the vertical distribution of the eggs should not be much affected by temperature as long as there is no ice cover to prevent wind mixing.

Egg releases were simulated from March 15 until April 30 from 3 locations: the 2 most important natural spawning grounds in Trondheimsfjorden (Verrabotn and Verrasundet; J. Mork unpubl. data) and 1 farming location (Fjøsvika at Ytterøya) (Fig. 2). As the farmed cod stock may spawn 10 to 100 times more eggs than the wild cod stock in Trondheimsfjorden (J. Mork unpubl. data), we 'released' 5 times more eggs in the model from the fish farm compared to the spawning grounds. At the natural spawning grounds, 10 eggs were released from 11 to $20 \mathrm{~m}$ over the bottom in $1 \mathrm{~m}$ intervals; at the fish farms, 100 eggs were released from 5 to $25 \mathrm{~m}$ depth in $0.2 \mathrm{~m}$ intervals. In sum 120 eggs were released every half hour until Day 47, which totals $>270000$ eggs over the spawning season.

The buoyancy of eggs was calculated according to Dallavalle (1948) and was valid for Reynolds numbers between 0.5 and 5 . We found this more realistic than Stokes formula, which is better suited for still water conditions where viscous forces are more important compared to turbulent forces (Sundby 1997, Knutsen et al. 2001). Eggs diameter and density were defined as $1.4 \mathrm{~mm}$ and 1.026 (Kjesbu et al. 1992), respectively, and were assumed to have this buoyancy for 84 day degrees before hatching (J. Mork unpubl. data). Afterwards, larvae and juveniles were treated as passive particles for a total drift time of up to 6 mo.

\section{Prediction of survival of eggs from farmed Atlantic cod}

The results from the current project and available data on hatching and survival rates of cod were used to develop 2 simple scenario models that predict survival of escaped eggs and larvae under various conditions. Using data on the sex ratio in farms, proportion of mature individuals after $\sim 1$ and $2 \mathrm{yr}$ in the sea (farmed cod are usually slaughtered before they reach 3 yr of age) and number of eggs hatched per female, we estimated the total number of yolk-sac larvae produced by a typical farmed female. Existing knowledge on subsequent survival of cod larvae, juveniles and sub-adults was used to estimate survival to $3 \mathrm{yr}$ old fish (Table 3 ). Based on results from the current study (see below) we assumed that 50 and $100 \%$ of the females spawn after $\sim 1$ and $2 \mathrm{yr}$ in the sea, respectively. The average sizes of 1 and $2 \mathrm{yr}$ old farmed females were set to 1 and $2.5 \mathrm{~kg}$, respectively. Data on survival from spawned egg to later life stages incorporates both fertilization and hatching rate (Table 3), assuming that sperm availability in

Table 3. Gadus morhua. Survival estimates of Atlantic cod used in the scenario models. Fishing mortality $\left(Z_{i} \mathrm{~d}^{-1}\right.$ or $\left.\mathrm{yr}^{-1}\right)$ was either incorporated in the total mortality estimates or assumed to be zero for younger stages. Survival \% is calculated from $Z$ and indicates the survival through different life stage periods as indicated in the first column. NCC: Norwegian coastal cod, NEAC: North-east Arctic cod. Italics: values used in the scenario models

\begin{tabular}{|lcccl|}
\hline Life history stage, survival & $\mathrm{Z}$ & Survival (\%) & Cod origin & Source \\
\hline Model 1 & & & & \\
Spawning to hatching (16 d) & $0.186 \mathrm{~d}^{-1}$ & 5.1 & NCC & Kristiansen et al. (1997) \\
Hatching to 1 yr old fish & $13.02 \mathrm{yr}^{-1}$ & 0.000223 & NCC & Kristiansen et al. (1997) \\
1-2 yr of age & $0.55 \mathrm{yr}^{-1}$ & 57.7 & NCC & Julliard et al. (2001) \\
1-2 yr of age & $1.31 \mathrm{yr}^{-1}$ & 27.0 & NCC & Larsen \& Pedersen (2002) \\
Mean (survival: 1-2 yr) & & 42.4 & NCC & \\
2-3 yr of age & $1.05 \mathrm{yr}^{-1}$ & 35.0 & NCC & Julliard et al. (2001) \\
2-3 yr of age & $1.33 \mathrm{yr}^{-1}$ & 26.4 & NCC & Kristiansen et al. (2000) \\
2-3 yr of age & $0.45 \mathrm{yr}^{-1}$ & 63.8 & NCC & Pedersen \& Pope (2003) \\
Mean (survival: 2-3 yr) & & 41.7 & NCC & \\
Model 2 & & & & \\
Spawning to hatching & & 10.0 & NEAC & Fossum (1988), Sundby et al. (1989) \\
0-90 d & $34.7 \mathrm{yr}^{-1}$ & 0.0184 & NEAC & Sundby et al. (1989) \\
90-180 d & $8.1 \mathrm{yr}^{-1}$ & 13.5 & NEAC & Sundby et al. (1989) \\
180 d-3 yr of age & $0.8 \mathrm{yr}^{-1}$ & 12.3 & Sundby et al. (1989) \\
\hline
\end{tabular}


farms is not a limiting factor. Finally, existing data on fish body growth rates was used to estimate biomass production from eggs spawned in sea-cages (Froese \& Pauly 2012). Potential density-dependent processes were not taken into account; however, if they occur our survival and biomass estimates should be regarded as overestimates. Fishing mortality is either incorporated in the total mortality estimates or assumed to be zero for younger stages.

Two scenario models were developed. The first model (Model 1) simulates survival of eggs and larvae from farms located in sheltered coastal locations (Table 3). This model is in part based on results from a study where genetically marked farmed cod were allowed to spawn under controlled conditions (Kristiansen et al. 1997). This marker made it possible to separate larvae and juveniles from farmed and wild cod spawning simultaneously in the same area and to estimate the survival of eggs from farmed cod until $1 \mathrm{yr}$ of age. Survival rates from 1 to $3 \mathrm{yr}$ of age are based on several studies where survival in the wild was estimated for Norwegian coastal cod (NCC), which was also used in Kristiansen et al. (1997) (Table 3). The second scenario model (Model 2) is based on estimated mean survival rates between 1979 and 1988 for North-east Arctic cod, which is the major population of Atlantic cod in western and northern Norway (Sundby et al. 1989). The values estimated in the 2 scenario models were number and biomass of surviving $3 \mathrm{yr}$ old fish, escaped as spawned eggs, per farmed fish (both males and females). The basic model was:

$R_{3 \mathrm{yr}}=W_{\mathrm{F}} \times$ Spawning proportion $\times$ Relative $F_{\mathrm{R}} \times S_{3 \mathrm{yr}}$

where $R_{3 \mathrm{yr}}$ is the number of $3 \mathrm{yr}$ old fish produced per farmed female, $W_{\mathrm{F}}$ is the average weight of farmed females just prior to spawning in kg, Spawning proportion is the assumed average percentage of either 1 or 2 yr old females spawning in sea-cages, Relative
$F_{\mathrm{R}}$ is the mean estimated $F_{\mathrm{R}} \mathrm{kg}^{-1}$, and $S_{3 \mathrm{yr}}$ is the assumed survival for the 2 scenarios until $3 \mathrm{yr}$ of age (Table 3).

When estimating the number of 3 yr old 'semi-wild' fish produced per farmed fish, the sex ratio was taken into account since the basic model estimates number of fish per farmed female only. Hence, the biomass per fish in the farm was estimated by multiplying numbers of first generation cod produced per farm fish with the calculated gross average weight of cod along the Norwegian coast at 3 yr of age (Froese \& Pauly 2012).

\section{RESULTS}

\section{Extent, frequency and timing of spawning of farmed Atlantic cod}

The average sex ratio determined for 6 farms $(\mathrm{N}=$ 4821) was close to 50:50 (females: males, 50.2:49.8\%). The maturation rates for females examined during the first year in the sea (first spawning season) varied from 46.5 to $86.2 \%$ for the 4 farms without artificial light (Table 4). Maturation rates for males from the same farms were higher with $>87 \%$ of the males being mature in 3 of these farms (Table 4). Artificial light was applied to only 1 of the examined farms (Gildeskål). Cod in this farm had been transferred to sea-cages 2 to 3 mo later than the other farms and were therefore also smaller; no mature fish were found in the samples from Gildeskål (Table 4). Almost all fish that were sampled during the second spring (i.e. second spawning season) across 4 seacage farms ( $\mathrm{n}=252$; Ytterøya, Røsnes, Lyngen and Tysfjord farms) were mature, with the exception of 4 males from the Ytterøya farm.

Gonadal developmental stage for fish from the Ytterøya farm (Fig. 1) indicated that a higher proportion of males were ripe on 2 November 2009 com-

Table 4. Gadus morhua. Percentages of 1+ yr old Atlantic cod that had ripe gonads (males and females separately) and would spawn during the first 12 to 14 mo in sea-cages. Additional details given are sampling date, usage of artificial light in sea-cages, husbandry period at sea, length and weight of cod and sample size (N)

\begin{tabular}{|c|c|c|c|c|c|c|c|c|c|}
\hline \multirow{2}{*}{ Farm } & \multirow{2}{*}{$\begin{array}{c}\text { Sampling } \\
\text { date }\end{array}$} & \multirow{2}{*}{$\begin{array}{l}\text { Artificial } \\
\text { light }\end{array}$} & \multirow{2}{*}{$\begin{array}{c}\text { Approx. } \\
\text { period } \\
\text { in sea }(y r)\end{array}$} & \multirow{2}{*}{$\begin{array}{c}\text { Length } \\
\text { (mean } \pm \text { SD } \\
\mathrm{mm})\end{array}$} & \multirow{2}{*}{$\begin{array}{c}\text { Weight } \\
\text { (mean } \pm \text { SD, } \\
\text { g) }\end{array}$} & \multicolumn{2}{|c|}{ Females } & \multicolumn{2}{|c|}{ Males } \\
\hline & & & & & & $\mathrm{N}$ & $\begin{array}{c}\text { Mature } \\
(\%)\end{array}$ & $\mathrm{N}$ & $\begin{array}{c}\text { Mature } \\
(\%)\end{array}$ \\
\hline Austevoll & 8 Mar 2011 & No & $\sim 1.3$ & $422 \pm 27$ & $932 \pm 147$ & 29 & 86.2 & 24 & 95.8 \\
\hline Frøya & 5 Nov 2009 & No & $\sim 1$ & $401 \pm 67$ & $751 \pm 343$ & 47 & 48.9 & 53 & 50.9 \\
\hline Gildeskål & 10 Mar 2011 & Yes & $\sim 0.8$ & $372 \pm 33$ & $372 \pm 216$ & 49 & 0 & 51 & 0 \\
\hline Røsnes & 15 Feb 2011 & No & $\sim 1$ & $447 \pm 30$ & $1126 \pm 254$ & 54 & 57.4 & 49 & 87.8 \\
\hline Lyngen & 23 Feb 2011 & No & $\sim 1$ & $444 \pm 30$ & $1110 \pm 259$ & 43 & 46.5 & 57 & 89.5 \\
\hline
\end{tabular}


pared to females (Fig. 3). The gonad stage index peaked in the last measurement, indicating that much of the spawning took place in March and April at the Ytterøya farm. Time of start of spawning was estimated through measurements of oocyte size for 3 farms (assumed average ocean temperature: $5^{\circ} \mathrm{C}$ ) (Fig. 4). In the 2 northernmost farms, most females commenced spawning in April. In the Ytterøya farm, the spawning season was more lasting; some females started spawning in February, whereas most initiated spawning in March and April. Because Atlantic cod are batch spawners with an individual spawning period of 3 to 6 wk (Chambers \& Waiwood 1996, Kjesbu et al. 1996), is it is reasonable to assume that spawning in sea-cages mainly occurred from March to June in the 2 northernmost farms, and also during February in the southernmost farm.

The potential, realised and relative fecundity varied among farms (Table 5). Females from the Røsnes farm were more productive compared to females from the 2 other farms. The overall mean number of eggs estimated to be spawned per $\mathrm{kg}$ female was $629400( \pm$ SD 219700$)$. In addition, $F_{p}$ decreased with increasing leading cohort oocyte diameter (Univariate GLM, LC: $F=15.9, \mathrm{df}=1, \mathrm{p}<0.001$; Farm: $F=9.3, \mathrm{df}=2, \mathrm{p}<0.001)$. When farm and LC were taken into account, $F_{\mathrm{p}}$ increased with increasing body weight $(F=36.5, \mathrm{df}=1, \mathrm{p}<0.001)$, while it was not significantly associated with somatic condition $(F<0.1, \mathrm{df}=1, \mathrm{p}=0.98)$.

\section{Evaluation of egg quality of farmed and wild Atlantic cod}

Fatty acid composition of eggs varied both between wild and farmed fish, and between the 2 farms included in the analysis (Fig. 5). A discriminant analysis on the 4 significant principal components showed that all females could be classified

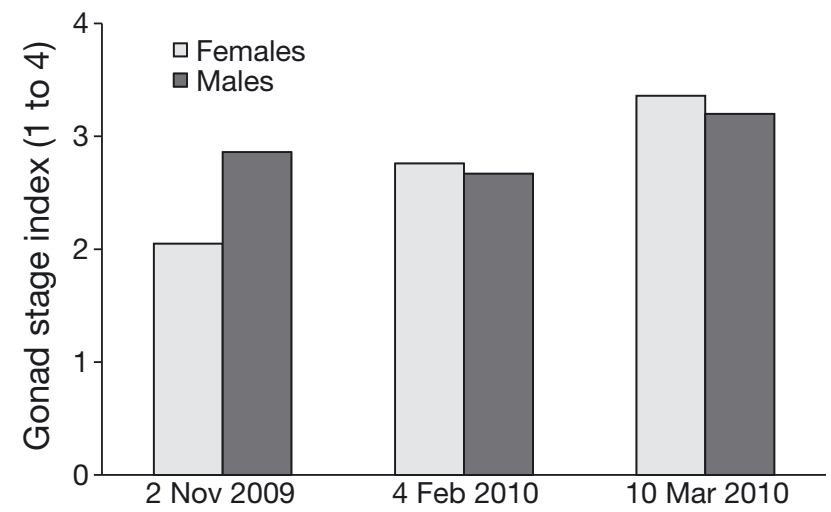

Fig. 3. Gadus morhua. Gonad stage index for Atlantic cod at the Ytterøya farm at different points of time. Gonads: undeveloped (1) to ripe (4)

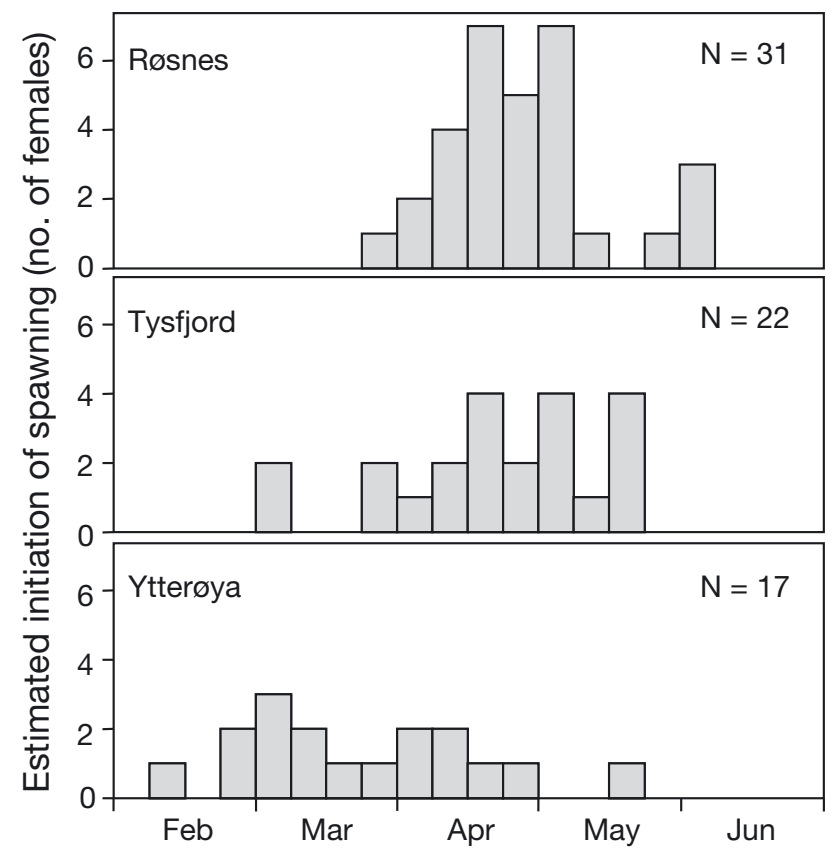

Fig. 4. Gadus morhua. Estimated initiation of time of spawning for 2 yr old female Atlantic cod at 3 farms by date. Average ocean temperature assumed to be $5^{\circ} \mathrm{C}$

Table 5. Gadus morhua. Summary of fecundity data (means \pm SD) of the 2 yr old female Atlantic cod from 3 farms used for fecundity analyses. Only females with vitellogenic oocytes were used. Potential fecundity: standing stock of maturing oocytes per female, Relative fecundity: potential fecundity per gram wet body weight, Realised fecundity: standing stock of oocytes before spawning corrected for subsequent atresia. Different superscript letters: differences among farms, same letters $=$ no difference (1-way ANOVA with Tukey's post hoc tests, $\mathrm{p}<0.05)$

\begin{tabular}{|lcccccc|}
\hline Farm & $\mathrm{N}$ & $\begin{array}{c}\text { Oocyte } \\
\text { diameter } \\
(\mu \mathrm{m})\end{array}$ & $\begin{array}{c}\text { Leading cohort } \\
\text { oocyte diameter } \\
(\mu \mathrm{m})\end{array}$ & $\begin{array}{c}\text { Potential } \\
\text { fecundity } \times 1000 \\
\left(F_{\mathrm{p}}\right)\end{array}$ & $\begin{array}{c}\text { Relative } \\
\text { fecundity } \\
\left(F_{\mathrm{p}} \mathrm{g}^{-1}\right)\end{array}$ & $\begin{array}{c}\text { Realised } \\
\text { fecundity } \\
\left(\mathrm{oocytes} \mathrm{g}^{-1}\right)\end{array}$ \\
\hline Ytterøya & 17 & $565 \pm 83^{\mathrm{b}}$ & $712 \pm 86^{\mathrm{b}}$ & $3226 \pm 1198^{\mathrm{b}}$ & $1379 \pm 380^{\mathrm{b}}$ & $656 \pm 272^{\mathrm{ab}}$ \\
Tysfjord & 22 & $512 \pm 60^{\mathrm{a}}$ & $632 \pm 72^{\mathrm{a}}$ & $3688 \pm 1120^{\mathrm{b}}$ & $1382 \pm 317^{\mathrm{b}}$ & $511 \pm 184^{\mathrm{b}}$ \\
Røsnes & 31 & $491 \pm 47^{\mathrm{a}}$ & $622 \pm 60^{\mathrm{a}}$ & $4870 \pm 1052^{\mathrm{a}}$ & $1651 \pm 313^{\mathrm{a}}$ & $699 \pm 179^{\mathrm{a}}$ \\
\hline
\end{tabular}




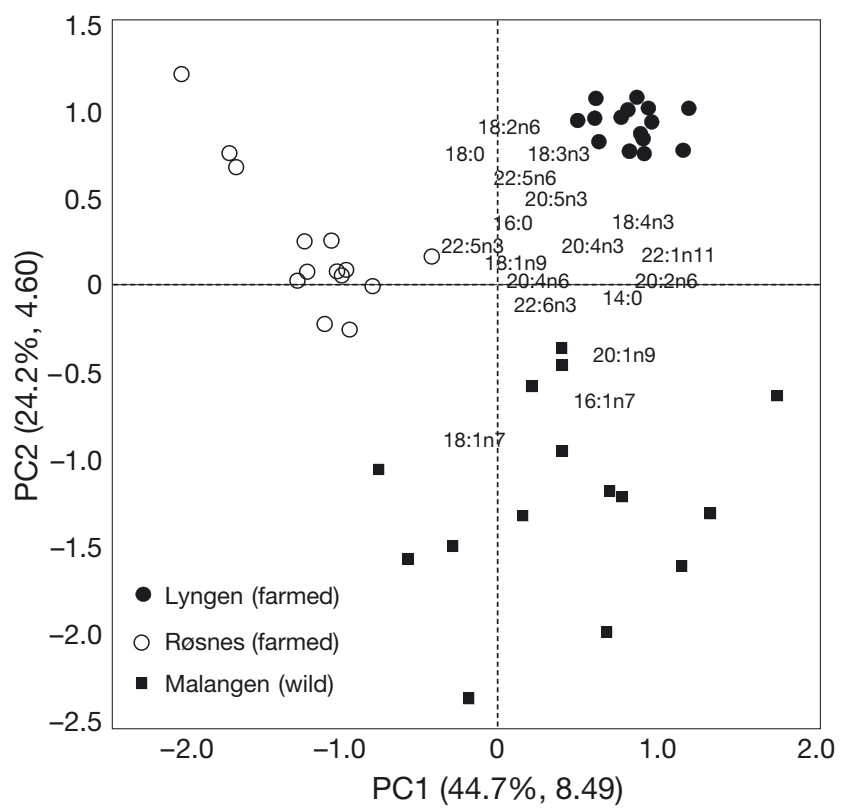

Fig. 5. Gadus morhua. Principal component (PC) analysis of fatty acids in eggs from farmed and wild Atlantic cod in relation to their origin. Individual factor scores and loadings for PCs 1 and 2 (with \% variation explained and eigenvalues in parentheses)

correctly according to their origin on the basis of variation in fatty acid profiles (Table 6). Eggs from farmed fish contained proportionally more saturated and polyunsaturated fatty acids (PUFAs) than wild fish, whereas the levels of monounsaturated fatty acids were highest in eggs from wild fish (Fig. 5, Table 7). The proportions of total n-3 PUFAs did not vary significantly among the 3 groups, but the levels of eicosapentaenoic acid (EPA, C20:5n3) and n-3 docosapentaenoic acid (DPA, C22:5n3) were higher in eggs from farmed fish, while the level of docosahexaenoic acid (DHA, C22:6n3) was highest for wild fish (Table 7). The proportions of total n-6 PUFAs were approximately twice as high for eggs from farmed fish compared to wild fish (Table 7). This was basically due to the levels of linoleic acid (LA, C18:2n6) and n-6 docosapentaenoic acid (DA, C22:5n6) in eggs from farmed fish that were 2 to
4 times higher than for wild fish (Table 7, Fig. 6). Arachidonic acid (AA, C20:4n6) levels did not vary among the groups (Table 7, Fig. 6), while fish from the Røsnes farm had less eicosadienoic acid (EA, C20:2n6) compared to the 2 other groups (Table 7). As a consequence of the high n-6 PUFA levels, the n-3:n-6 ratio for eggs from wild fish was approximately twice that of farmed fish (Fig. $6 ; F=53.7, \mathrm{p}<$ 0.001). The DHA:EPA ratio from wild fish eggs was higher than for eggs from the 2 farms (Fig. $6 ; F=$ 30.6, $\mathrm{p}<0.001)$, but there was little variation in EPA:AA ratio among the 3 groups (Fig. $6 ; F=0.1$, $p=0.9$ ). The egg lipid content (proportion of dry wt \pm SD) was not significantly different between eggs from the Røsnes farm $(11.7 \pm 1.5 \%)$ and wild fish $(12.2 \pm 1.0 \%)$, but eggs from the Lyngen farm $(13.1 \pm 0.8 \%)$ contained higher levels of lipid than eggs from wild fish $(F=5.7, \mathrm{p}=0.007)$.

\section{Dispersal of Atlantic cod eggs from farms}

The applied hydrodynamics model showed that the first eggs from the natural spawning ground of Verrasundet enter Beitstadfjorden after $4 \mathrm{~d}$, while the eggs from Verrabotn, located further into this narrow branch of Trondheimsfjorden, did so after $\sim 14 \mathrm{~d}$ (Figs. 2 \& 7). Overall there is an anticyclonic circulation in this fjord system and particles coming through Verrasundet typically have an anticyclonic path into central Beitstadfjorden. In contrast to this, after $20 \mathrm{~d}$, the first eggs from the Fjøsvika farm (Ytterøy) exit the fjord at Agdenes (Figs. $2 \& 7$ ). At this time, there was a high concentration of farmed eggs from the Tautra sill and inwards to Skarnsundet (Figs. 2 \& 7). In Beitstadfjorden, mixing of eggs from all 3 sites took place at this point and about a third of the eggs were from the farm (Figs. 2 \& 7). At $28 \mathrm{~d}$ after simulated initiation of spawning, eggs from the farm were spread all over the fjord except from Verrasundet, and their concentration was higher along the northern side of the fjord. At this time, however, farmed eggs start to enter Verrasundet as well, while $22 \%$ of all naturally spawned eggs still remained within this fjord arm.

Table 6. Gadus morhua. Test statistics from the discrimination analysis regarding separation of farmed and wild Atlantic cod on the basis of 4 significant principal components (PCs)

\begin{tabular}{|lcccccccccc}
\hline Model & $F$ & $\begin{array}{c}\text { Eigen- } \\
\text { value }\end{array}$ & $\begin{array}{c}\text { Canonical } \\
\text { correlation }\end{array}$ & Wilk's $\lambda$ & $\chi_{2}^{2}$ & df & p & & Ytterøya farm $\begin{array}{c}\text { Correct classification (\%) } \\
\text { Røsnes farm Malangen wild }\end{array}$ \\
\hline Ovaries & 1 & 37.3 & 0.98 & 0.01 & 206 & 8 & $<0.001$ & 100 & 100 \\
$(\mathrm{PC} 1,2,3,4)$ & 2 & 3.8 & 0.89 & 0.21 & 62 & 3 & $<0.001$ & & 100 \\
\hline
\end{tabular}


Table 7. Gadus morhua. Fatty acid composition (\% of weight excluded unknown fatty acids) of total lipids from running (unfertilized) eggs from broodstock of Atlantic cod from 3 farms. Means of duplicates and SD. Significant differences $(p<0.05)$ determined by 1 -way ANOVA with Tukey's post-hoc tests indicated by differing letters in the 2 rightmost columns; same letter $=$ no difference; smallest (a) to largest (c) mean. NS: not significant. R: Røsnes farm, L: Lyngen farm, M: Malangen bank, W: wild cod, F: farmed cod

\begin{tabular}{|c|c|c|c|c|c|c|c|c|}
\hline \multirow{2}{*}{$\begin{array}{l}\text { Fatty } \\
\text { acid }\end{array}$} & \multicolumn{2}{|c|}{ Røsnes (F) } & \multicolumn{2}{|c|}{ Lyngen (F) } & \multicolumn{2}{|c|}{ Malangen (W) } & \multicolumn{2}{|c|}{$\mathrm{p}<0.05$} \\
\hline & Mean & $\mathrm{SD}$ & Mean & $\mathrm{SD}$ & Mean & $\mathrm{SD}$ & $\mathrm{R} / \mathrm{L} / \mathrm{M}$ & $\mathrm{W}$ vs. $\mathrm{F}$ \\
\hline $\mathrm{C} 14: 0$ & 1.72 & 0.11 & 2.00 & 0.13 & 2.04 & 0.30 & $a b b$ & NS \\
\hline C16:0 & 21.74 & 0.44 & 20.38 & 0.35 & 19.30 & 0.54 & $\mathrm{c} \mathrm{b} \mathrm{a}$ & $\mathrm{b}$ a \\
\hline C18:0 & 2.86 & 0.43 & 2.71 & 0.28 & 1.56 & 0.26 & $\mathrm{~b} \mathrm{~b} a$ & $\mathrm{~b} a$ \\
\hline Total saturated & 26.32 & 0.35 & 25.09 & 0.35 & 22.90 & 0.56 & $\mathrm{c} \mathrm{b}$ a & $\mathrm{b}$ a \\
\hline C16:1n7 & 2.87 & 0.30 & 3.21 & 0.33 & 4.37 & 0.67 & $\mathrm{a} a \mathrm{~b}$ & $\mathrm{ab}$ \\
\hline C18:1n9 & 12.34 & 0.51 & 11.83 & 0.51 & 11.85 & 0.85 & NS & NS \\
\hline C18:1n7 & 3.92 & 0.13 & 3.13 & 0.15 & 4.95 & 0.82 & b a c & $\mathrm{ab}$ \\
\hline C20:1n9 & 0.88 & 0.10 & 1.82 & 0.13 & 3.30 & 0.89 & $\mathrm{a} b \mathrm{c}$ & $\mathrm{ab}$ \\
\hline C22:1n11 & 0.25 & 0.06 & 0.70 & 0.07 & 0.73 & 0.23 & $\mathrm{a} b \mathrm{~b}$ & NS \\
\hline $\mathrm{C} 24: 1$ & 0.33 & 0.15 & 0.54 & 0.09 & 0.44 & 0.14 & $\mathrm{a} b \mathrm{a}$ & NS \\
\hline Total monoenes & 20.59 & 0.89 & 21.23 & 0.62 & 25.63 & 0.84 & $\mathrm{a} a \mathrm{~b}$ & $\mathrm{ab}$ \\
\hline C18:3n3 & 0.30 & 0.01 & 0.51 & 0.02 & 0.24 & 0.05 & $\mathrm{bc} \mathrm{a}$ & $\mathrm{b}$ a \\
\hline C18:4n3 & 0.39 & 0.04 & 0.72 & 0.03 & 0.57 & 0.12 & $\mathrm{a} \mathrm{c} \mathrm{b}$ & NS \\
\hline $\mathrm{C} 20: 4 \mathrm{n} 3$ & 0.30 & 0.02 & 0.33 & 0.02 & 0.32 & 0.03 & $\mathrm{a} b \mathrm{~b}$ & NS \\
\hline $\mathrm{C} 20: 5 \mathrm{n} 3$ & 18.22 & 0.89 & 19.09 & 0.59 & 16.46 & 1.15 & $\mathrm{bca}$ & $\mathrm{b}$ a \\
\hline $\mathrm{C} 22: 5 \mathrm{n} 3$ & 1.66 & 0.12 & 1.48 & 0.07 & 1.39 & 0.36 & $\mathrm{bc} \mathrm{a}$ & $\mathrm{b}$ a \\
\hline $\mathrm{C} 22: 6 \mathrm{n} 3$ & 27.51 & 1.16 & 26.02 & 0.88 & 29.62 & 2.07 & $\mathrm{~b}$ a c & $\mathrm{ab}$ \\
\hline Total n-3 PUFA & 48.38 & 1.01 & 48.16 & 0.57 & 48.61 & 1.42 & NS & NS \\
\hline C18:2n6 & 2.67 & 0.08 & 3.21 & 0.10 & 0.86 & 0.15 & $\mathrm{~b} \mathrm{c} \mathrm{a}$ & $\mathrm{b}$ a \\
\hline C20:2n6 & 0.13 & 0.04 & 0.22 & 0.02 & 0.20 & 0.02 & $\mathrm{a} b \mathrm{~b}$ & NS \\
\hline $\mathrm{C} 20: 4 \mathrm{n} 6$ & 1.63 & 0.16 & 1.74 & 0.12 & 1.63 & 0.66 & NS & NS \\
\hline $\mathrm{C} 22: 5 \mathrm{n} 6$ & 0.28 & 0.02 & 0.36 & 0.02 & 0.17 & 0.10 & $\mathrm{~b} \mathrm{c} \mathrm{a}$ & $\mathrm{b} a$ \\
\hline Total n-6 PUFA & 4.71 & 0.16 & 5.53 & 0.22 & 2.86 & 0.70 & $\mathrm{bc} \mathrm{a}$ & $\mathrm{b}$ a \\
\hline Total PUFA & 53.09 & 0.89 & 53.68 & 0.51 & 51.47 & 0.98 & $\mathrm{~b} b \mathrm{a}$ & $\mathrm{b}$ a \\
\hline Unknown & 4.01 & 0.34 & 4.67 & 0.47 & 5.08 & 0.58 & $\mathrm{a} b \mathrm{~b}$ & NS \\
\hline
\end{tabular}

were caught in eddies in the Seaward Basin and spread, while most continued along the northern side of Trondheimsfjorden toward the coast. About $6 \%$ of the eggs from the farm had been advected out of the fjord, while $0.1 \%$ of the naturally spawned eggs had been exported at this time. Drift time out of the model area from the farm was on average $29 \mathrm{~d}$, with a range of $\sim 17$ to $44 \mathrm{~d}$. From the 2 spawning grounds inside Verrafjorden, the average drift time out of the model area was $36 \mathrm{~d}$, with a range of $\sim 28$ to $41 \mathrm{~d}$.

\section{Prediction of survival of eggs from farmed Atlantic cod}

The scenario model based on estimated survival rates of both farmed and wild coastal cod (Model 1) resulted in a considerable lower number of $3 \mathrm{yr}$ old 'semi-wild' cod due to spawning in cages compared to the model which was based on estimated survival rates of North-east Arctic cod (Model 2, Table 8). For instance, Model 1 and 2 result in 1140 and 17280 three-yr old cod,
After $56 \mathrm{~d}$, eggs from the 2 spawning grounds were mixed over much of the fjord, but there were also localized pockets where little mixing occurred. Their concentration north of Skarnsundet was high, and they tended to follow the northern side of Midtfjorden outwards beyond the Tautra sill. Some respectively, if applied to a typical sea-cage with 60000 cod (Table 8). The biomass produced by spawning in sea-cages is thus much higher for Model 2 compared to Model 1, and lower for spawning during the first season compared with the second (Table 8).

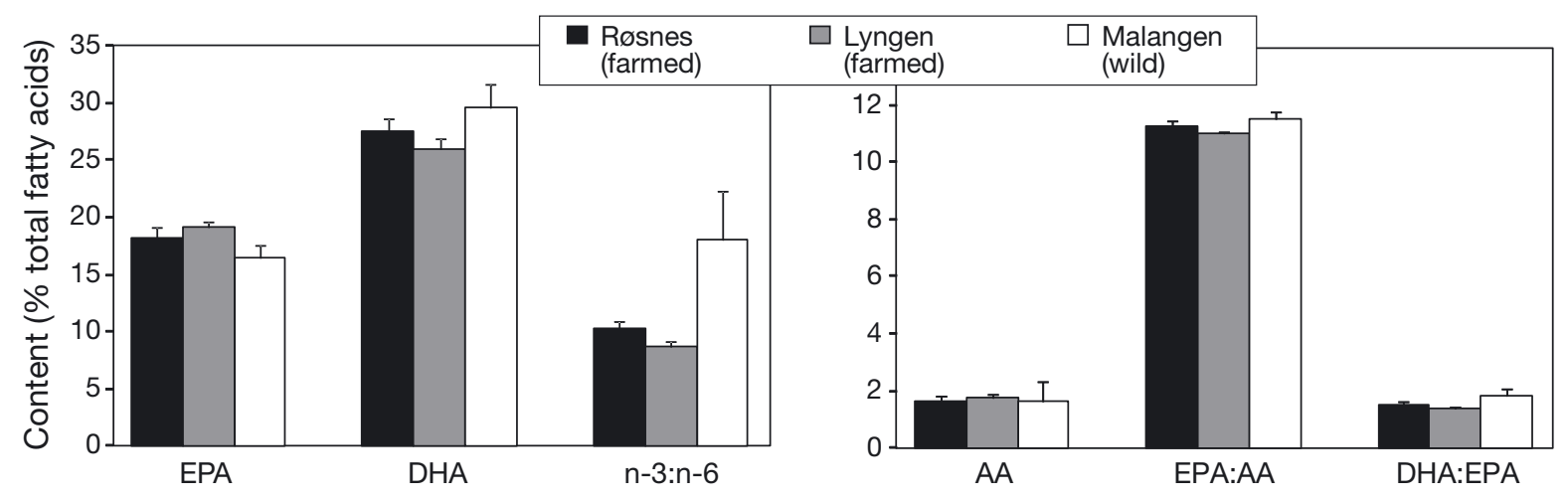

Fig. 6. Gadus morhua. Proportions (means \pm SD) of eicosapentaenoic (EPA), docosahexaenoic (DHA) and aracidonic (AA) acids, and n3:n6, EPA:AA and DHA:EPA ratios of total fatty acids of Atlantic cod eggs. Unknown fatty acids were excluded 

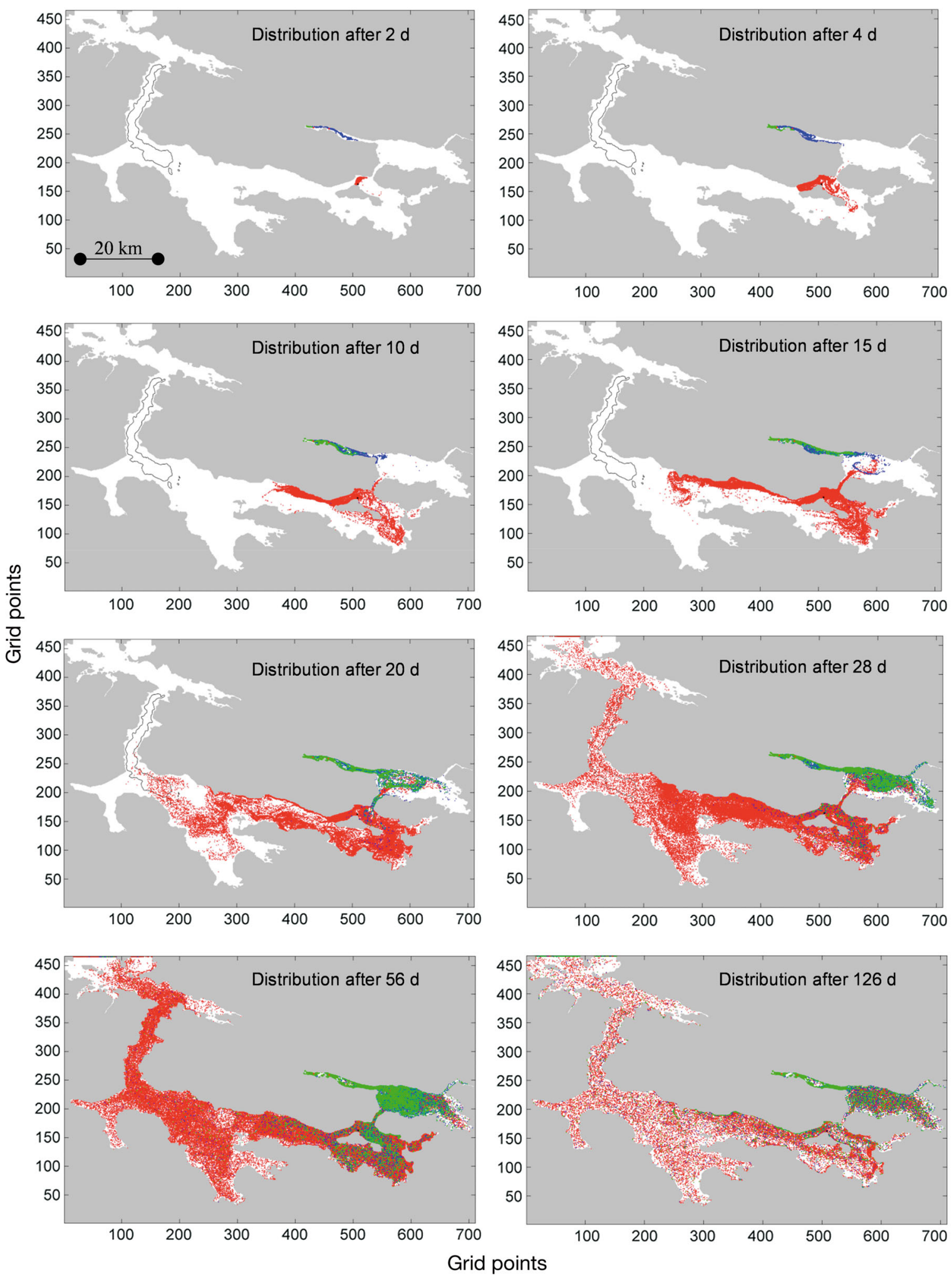

Fig. 7. Gadus morhua. Spread of simulated escaped and wild spawned Atlantic cod eggs and larvae in Trondheimsfjorden after 2, 4, 10, 15, 20, 28, 56 and 126 d. Eggs spawned in Verrabotn (green), Verrasund (blue), and farmed eggs (red). Farmed eggs become distributed effectively over most of the fjord, while the naturally spawned eggs have a significantly more restricted distribution at the beginning. On Day 126 the particle density was greatly reduced compared with Day 56 due to export of particles from the fjord. See Fig. 2 for details of Trondheimsfjorden 
Table 8. Gadus morhua. Overview of results from the scenario models. Number and biomass of 3 yr old Atlantic cod escapees originating from spawning in cages presented either per farm fish or for a 'typical' sea-cage holding 60000 fish

\begin{tabular}{|lccrr|}
\hline $\begin{array}{l}\text { Spawning } \\
\text { year }\end{array}$ & \multicolumn{2}{c|}{$\begin{array}{c}\text { Per farm fish } \\
\text { Number }\end{array}$} & $\begin{array}{r}\text { Biomass } \\
(\mathrm{kg})\end{array}$ & Per sea-cage \\
Number & $\begin{array}{r}\text { Biomass } \\
(\mathrm{kg})\end{array}$ \\
\hline Model 1 & & & & \\
$\begin{array}{l}\text { First year } \\
\text { Second year }\end{array}$ & 0.003 & 0.004 & 180 & 219 \\
Model 2 & 0.016 & 0.019 & 960 & 1169 \\
$\begin{array}{l}\text { First year } \\
\text { Second year }\end{array}$ & 0.048 & 0.058 & 2880 & 3508 \\
& 0.240 & 0.292 & 14400 & 17539 \\
\hline
\end{tabular}

\section{DISCUSSION}

We have demonstrated that a large proportion of farmed Atlantic cod mature in industrial sea-cages both the first and second year of sea-based culture and that the fecundity of farmed cod is high. Furthermore, while the fatty acid composition of farmed and wild cod eggs differed, farmed cod eggs are likely to produce viable larvae upon escape from cages. Egg dispersal modelling suggested that mixing of farmed and wild cod eggs will occur in most parts of a fjord ecosystem and that progeny from both types of fish will experience similar environments, given that farmed cod spawn during the wild cod spawning season. Farms examined during this study were spread over a broad latitudinal range of cod farming; thus the results are likely to be relevant at an industrywide scale. Taken together with previous studies that have indicated that escaped farmed cod eggs can survive until reproductive age (van der Meeren et al. 2012), our data show that spawning and egg release from sea-cages is a significant process that may have ecological repercussions for these ecosystems unless the extent of spawning within sea-cages is reduced.

\section{Extent, frequency and timing of spawning of Atlantic cod}

The natural spawning season of cod in Norway is late winter and early spring. Farmed cod also spawn during this period, although specimens that experience artificial light regimes may spawn at different times compared with wild cod (Hansen et al. 2001, Karlsen et al. 2006, Taranger et al. 2006). However, to evaluate the ecological importance of escape of farmed cod through spawning in sea-cages, further knowledge on the extent, frequency and timing of spawning is required.
Our results showed that between 47 and $86 \%$ of the females reared under natural light conditions were sexually mature after $\sim 1 \mathrm{yr}$ in the sea. In the only farm where artificial light was applied, no fish matured during their first spring in sea-cages. This might be a result of the artificial light inhibiting maturation or that these fish were transferred to sea 2 to 3 mo later than the fish from the other farms. If cod juveniles are introduced into sea-cages the preceding summer (or later), the fish could be too small for females to be mature during the first spawning season, while some of the males could mature at weights as low as $300 \mathrm{~g}$ (Taranger et al. 2010). However, the maturation ratio of farmed cod during the first year (1+ fish) may be high even when artificial light is used. According to Trippel et al. (2008), application of continuous $24 \mathrm{~h}$ light within sea-cages compared to natural photoperiod resulted in a lower, but still high, percentage of mature females (73 versus $90 \%$ ) and males (90 versus $100 \%$ ). Results from the current study also show that all females and almost all males were mature after $2 \mathrm{yr}$ in the sea across the commercial farms investigated, which ground-truths similar results obtained in experimental settings (Svåsand et al. 1996, Hansen et al. 2001, Karlsen et al. 2006, Taranger et al. 2006, 2010).

The spawning seasons of the cod examined in the current study concur with previous observations for farmed cod (e.g. Otterå et al. 2006) and overlap with the natural season. In Norwegian waters, wild cod usually spawn during the winter and spring months (January to May), with considerable variation among populations. Typically, populations of cod spawn over a period of $<3$ mo (Brander 1994, Chambers \& Waiwood 1996, Kjesbu et al. 1996), and initiation of spawning may depend on environmental or genetic variation (Otterå et al. 2006). The finding that initiation of spawning varied among the examined farms may thus be both a result of environmental variation or that the origin of the farmed cod differed. As for other fish species with a pelagic egg stage, timing of spawning is likely to be an adaptation to maximize recruitment; too early or too late spawning may mean that the start-feeding larvae will miss the zooplankton bloom, i.e. the match-mismatch hypothesis (e.g. Ellertsen et al. 1981, Taggart \& Frank 1990, Pepin \& Myers 1991, Sundby 2000). Zooplankton occurrence was not monitored in the present study; it is therefore difficult to assess whether the spawning of farmed cod took place outside or inside the optimal window for spawning at the different locations. Nevertheless, spawning in cages occurred over a relatively long period, which in part would imply some degree of 
overlap. In our assessment of spawning season, the cod were reared under natural light conditions at all except for one farm. Manipulation of light conditions with artificial light sources in cages may delay the spawning time by several months (e.g. Hansen et al. 2001, Trippel et al. 2008, Taranger et al. 2010), potentially causing farmed cod to spawn outside the natural spawning season.

The standing stock of oocytes immediately before spawning (realised fecundity) corresponded to $\sim 630000$ eggs $\mathrm{kg}^{-1}$ body weight across the 3 examined farms. The fecundities we determined from commercial farms are similar or higher than earlier measurements of relative fecundity for farmed cod from experimental farms (Kjesbu et al. 1991, Kjesbu \& Holm 1994, Karlsen et al. 1995). Moreover, the estimated relative fecundity was higher than the typically recorded relative fecundity of wild cod (Botros 1962, Kjesbu 1989, Kjesbu et al. 1998). This is most likely related to the good nutrition provided during gonadal maturation for farmed cod (Kjesbu et al. 1991, Wroblewski et al. 1999).

\section{Quality of farmed and wild Atlantic cod eggs}

The quality of eggs and larvae is determinative for juvenile fish survival (e.g. Tocher 2010) and thus also to which degree farmed cod may produce 'escaped adult cod' through spawning in cages. We used the variation in biochemical composition of eggs as a proxy for egg quality. Egg fatty acid compositions can be affected by broodstock diet in various fish species (Tocher 2010), which in turn is important for production of high quality eggs and larvae (Tandler et al. 1995, Izquierdo et al. 2001, Pavlov et al. 2004, Salze et al. 2005, Fuiman \& Ojanguren 2011, Lanes et al. 2012). We used stripped, unfertilized cod eggs since we knew the origin of the eggs down to an individual level and since the male contribution through sperm should have little immediate effect on the biochemical composition of the eggs.

Fatty acid profiles of eggs from wild and farmed cod differed significantly, most likely as a result of their different diets. Recently, the fish feed industry has developed feeds that contain substantial amounts of vegetable-derived oils and meals of terrestrial origin that consist mainly of n-6 rather than n-3 PUFAs. Sunflower, soya bean, palm or rapeseed oils are used extensively in fish feed production and result in high concentrations of oleic $(18: 1 \mathrm{n} 9)$ and linoleic $(18: 2 \mathrm{n} 6)$ acids (Pickova \& Mørkøre 2007, Turchini \& Torstensen 2009). Cod eggs from farmed females contained
3 to 4 times more linoleic acid than eggs from wild fish, which supports the assumption that eggs of farmed cod are affected by parental diet.

Fatty acid compositions of the total lipids were relatively similar to those previously reported for cod eggs (e.g. Salze et al. 2005, Lanes et al. 2012) with respect to the total levels of saturated, monounsaturated and polyunsaturated fatty acids. However, several differences with respect to the levels of highly unsaturated fatty acids (HUFAs) were detected. HUFA levels have been reported to be related to egg and larval viability. In marine fish, including cod, 3 HUFAs have been shown to be particularly important for fertilization rates, hatching and early survival: EPA (20:5n3), DHA (22:6n3) and AA (20:4n6) (Pickova et al. 1997, Sargent et al. 1999a,b, Pavlov et al. 2004, Salze et al. 2005, Lanes et al. 2012). DHA is important for pelagic fish eggs and larvae (including cod) because neural tissues, such as brain and eyes, contain very high levels of it (Sargent et al. 1995, 2002). Furthermore, the levels of AA and the DHA: EPA ratio in eggs are usually positively correlated with egg and larval quality criteria, while the EPA: AA ratio is negatively correlated with performance of early life stages (Pickova et al. 1997, Salze et al. 2005, Lanes et al. 2012). We detected that wild cod eggs had higher levels of DHA and a greater DHA:EPA ratio compared with eggs from farmed cod. There was, however, no variation in EPA:AA ratio or AA levels among the wild and farmed cod. This finding contrasts with the results of Salze et al. (2005) who found significant differences among wild and farmed fish in AA levels, the EPA:AA ratio, and also egg performance. Lanes et al. (2012) also found that AA levels in cod eggs from wild broodstock were higher compared with eggs from farmed broodstock, but did not demonstrate any correlation between AA levels and egg quality parameters. The AA levels of wild fish found in the present study were $\sim 2$ times lower than those reported previously, but comparable with the levels found for farmed fish (Salze et al. 2005). However, variation in AA levels might also be under strong genetic influence and represent interpopulation variation in lipid composition (Pickova et al. 1997).

Thus, in agreement with previous studies, our results indicate that eggs from wild cod might be of better quality than farmed cod (Salze et al. 2005, Lanes et al. 2012), even though there was no difference in the levels of AA between wild and farmed cod. The lack of variation in AA may on the other hand suggest that the viability of eggs and larvae of farmed cod is not critically inferior to that of wild fish. 
This is further supported by the fact that cod on aquaculture diets both mature and spawn viable eggs that hatch, and fish survive to $3 \mathrm{yr}$ of age in the wild and contribute to the recruit pool in fjord and coastal populations of cod (Jørstad et al. 2008, van der Meeren et al. 2012). The ability to conclude whether viability differs between eggs and larvae from wild and farmed cod is nevertheless restricted because other biochemical components in cod eggs not measured in the current study also influence egg quality, such as vitamins and the proportion of major lipid classes (Salze et al. 2005, Lanes et al. 2012).

\section{Dispersal of Atlantic cod eggs from farms}

Wild cod often spawn in the same areas over time (Wright et al. 2006). It is likely that these areas are due to evolutionary selection processes and result in maintenance or dispersal of eggs and larvae such as to maximize subsequent survival and growth. Cod farms can be located close to spawning sites for wild cod. Simulations derived from the 3D dispersal model indicated that escaped eggs and larvae from a cod farm located within a fjord mixed with their wild counterparts. If the distributions of eggs and larvae from wild and farmed cod overlap in time and space, it is reasonable to assume that farmed and wild cod eggs and larvae would experience similar early life history environments. As long as egg and larval quality is similar, comparable survival rates between wild and farmed eggs may be expected. The possibility for farmed and wild larvae to mix will, however, most likely vary among locations and years. Potential may exist to reduce the degree of mixing of farmed and wild eggs in fjords if farming locations can be established whereby escaped eggs are rapidly transported out of the fjord system.

\section{Survival of eggs from farmed Atlantic cod}

Assumed that half of the females spawn during their first year in the sea and all during their second, Model 1 predicts that 333 farmed fish produce one $3 \mathrm{yr}$ old 'semi-wild' cod during the first year in the sea, while 63 fish are required during the second year. Correspondingly, Model 2 predicts that 21 farm fish would produce one $3 \mathrm{yr}$ old escapee during the first spawning season, while only 4 farm fish would produce one $3 \mathrm{yr}$ old escapee in the second season. These results indicate that the number of adult cod that originate from escaped eggs is 4 to 5 times higher for spawning during the second season in the sea compared with the first. This results from larger body size and higher fecundity and maturation rate. A further implication from the 2 scenarios is that survival will vary greatly under different conditions. The number of 'semi-wild' cod that survive to adulthood under disadvantageous conditions could be low, while spawning in sea-cages could produce considerable numbers of first generation adults under more optimal conditions. However, due to the wide range of variables that may influence egg quality, larval survival, recruitment and survival to adult size, the magnitude of farmed cod entry into wild cod populations through spawning in sea-cages would in practice be unpredictable. Nevertheless, in fjord systems or areas housing local cod stocks where cod farming is significant and where catches of wild cod may be only in the order of 10 s to 100 s of tons, the impact of spawning in sea-cages could be considerable. For instance, our scenarios suggest that a typical seacage with 60000 fish may produce 1.4 to $21 \mathrm{t}$ of first generation farmed cod through spawning in seacages. Given most cod farms have multiple cages of this size, the level of escape through spawning that this estimate suggests is significant when compared to known wild cod biomasses in specific fjord systems (e.g. Masfjord: total estimated wild cod biomass = $28 \mathrm{t}$; Salvanes \& Ulltang 1992). At this scale, recruitment of 3 yr old first generation farmed cod spawned in sea-cages has the potential to swamp recruitment through wild cod spawning.

The survival estimates from the 2 scenario models should be regarded as coarse estimates of possible survival rates of eggs and larvae until $3 \mathrm{yr}$ of age due to the many sources for variation in the underlying data. For instance, the proportions of mature females will vary among farms and whether artificial light has been used to manipulate maturity, which in turn will influence if eggs hatch during periods where food for the developing larvae is present. Fecundity will also vary among farms and ages and the accuracy of estimated survival rates for species with pelagic larvae are in general limited by numerous sources for variation due to methodological constraints and spatio-temporal variation in environmental parameters. In addition, the survival estimates may be overestimated, as it is likely that the survival of larvae from spawning during the first season would be lower than for spawning during the second season (e.g. Solemdal et al. 1993). This also concurs with recent experiences from the national cod breeding program in Norway, where first time spawners have resulted in much lower egg numbers and reduced 
production output compared to older broodstock (Ø. J. Hansen pers. comm.). Furthermore, the survival estimates are likely to be overestimates as sperm quality, and subsequent fertilisation success, is reduced for farmed males compared to wild males (Skjæraasen et al. 2009, Butts et al. 2011).

\section{Potential ecological effects of escaped Atlantic cod eggs}

Whether the escape of farmed cod through spawning in sea-cages results in negative ecological effects depends on several factors. Farmed cod experience strong artificial selection during their larval phase under intensive culture conditions and also through selective breeding for optimal aquaculture strains. This may change the genetic variability of farmed versus wild cod, which in theory may alter the fitness of wild cod through interbreeding between farm escapees and wild fish. However, occurrence of negative genetic effects due to egg escape depends on the existence of local adaptations in cod populations. Such adaptations have been difficult to demonstrate for Atlantic cod. While growing evidence exists for genetic and spatial divergence over the geographic range of Atlantic cod (Hauser \& Carvalho 2008, Knutsen et al. 2011, Skjæraasen et al. 2011), no conclusive evidence of a link between genetic differences and significant local adaptations exists. The genetic variability of cod is large and the potential for gene flow is high compared to other aquacultured species, such as Atlantic salmon Salmo salar. The probability that heritable local adaptations exist is therefore likely to be lower for cod than salmon. Nevertheless, we cannot exclude the potential for negative genetic effects, especially as intensive selective breeding to create optimal strains for aquaculture is underway. Further, cod are more prone to escape than salmon (Moe et al. 2007), and the possibility for escape of relatively large numbers of farmed cod exists, either through egg escape (present study) or escape of farmed fish (Bekkevold et al. 2006).

Paradoxically, escape of farmed cod through spawning in cages may increase 'wild' cod numbers, particularly if local adaptations are of minor importance and fitness is related to phenotypic plasticity. Demographic effects may result: increased recruitment may lead to greater numbers of smaller cod with lower growth rates due to density dependent competition. Correlative evidence exists that this process has occurred in Greece with escape through spawning of sea bream Sparus aurata (Dimitriou et al.
2007). However, the many environmental conditions in which farmed-wild hybrid fishes may be at a disadvantage in the wild could mean that any potential benefits of farmed-wild gene flow will be outweighed by its costs in natural situations in the long term (Hindar et al. 1991, Naylor et al. 2005, Hutchings \& Fraser 2008).

\section{Conclusions and recommendations to reduce the escape of Atlantic cod eggs from sea-cages}

Commercial cod farming as a whole has the potential to produce large amounts of eggs and larvae through spawning in sea-cages. The quality of these eggs and larvae may be sufficient for an unknown proportion of the larvae to survive until first feeding. Farmed and wild eggs and larvae mix in coastal ecosystems and experience similar larval environments. Survival of escaped cod eggs until adult fish may vary significantly and will also be unpredictable. Whether or not escape of cod eggs will generate significant ecological effects is difficult to foresee, but the results from this and other studies indicate that egg escape, in combination with escape of juveniles and adults (e.g. average of 213000 fish $\mathrm{yr}^{-1}$ from 2005 to 2009 in Norway; Jensen et al. 2010), may lead to noticeable effects in areas with intensive cod farming and small (reduced) wild fish populations.

The scenario models we developed assumed that farmed cod spawned in sea-cages both at 1 and $2 \mathrm{yr}$ of age. As a result of increased growth rates in commercial cod farming during the last 2 to $3 \mathrm{yr}$ due to selective breeding and improved production methods, it is now common that the desired slaughter size is reached before the second spawning season. This is an advantage for the farmers as the quality and price of farmed cod is higher before the second spawning compared to after spawning. Thus, if specific actions are required to mitigate potential future issues that may occur due to egg escape, a simple, realistic and profitable action to drastically reduce the risk of effects is to make slaughtering of fish before the second spawning season mandatory. In addition, photoperiod manipulation will decrease maturation ratio and fecundity, and delay the spawning time of farmed cod, both under controlled and commercial conditions (Hansen et al. 2001, Taranger et al. 2006, Trippel et al. 2008). As spawning during the first season in the sea produced 4 to 5 times fewer eggs than spawning during the second season, photoperiod manipulation will further reduce the potential for unwanted ecological effects of spawning in 
sea-cages. Combined, these actions will reduce the escape of cod eggs significantly.

Recent research has shown that production of triploid Atlantic cod may practically eliminate the risk of egg escape, as gamete production by triploid females is delayed and dramatically lowered compared to diploid females (e.g. Feindel et al. 2011). This is promising as it indicates that triploid females will not mature before harvest, and growth rates will increase through reduced investment in gonad production. However, problems such as initially higher mortality, greater fingerling costs, maturation of triploid males and consumer acceptance need to be solved before production of triploid fish is taken up by industry (Triantafyllidis et al. 2007, Feindel et al. 2010). Technical solutions aimed at physically preventing spawned eggs entering the sea have also been suggested. Such solutions could involve the use of closed sea-cages or mechanical filters to remove eggs. However, development of closed cages is still at an early stage and is presently economically nonviable due to high technological and operational costs.

Acknowledgements. Funding was provided by the European Union 7th Research Framework project 'Assessing the causes and developing measures to prevent the escape of fish from sea-cage aquaculture' (Prevent Escape; Grant agreement no. 226885) and the Norwegian Research Council projects EcoMA and iCoast.

\section{LITERATURE CITED}

Bekkevold D, Hansen MM, Nielsen EE (2006) Genetic impact of gadoid culture on wild fish populations: predictions, lessons from salmonids, and possibilities for minimizing adverse effects. ICES J Mar Sci 63:198-208

Botros GA (1962) Die Fruchtbarkeit des Dorsches (Gadus morhua L.) in der westlichen Ostsee und den westnorwegischen Gewässern. Kieler Meeresforsch 18:67-80

> Brander KM (1994) The location and timing of cod spawning around the British Isles. ICES J Mar Sci 51:71-89

Butts IAE, Trippel EA, Ciereszko A, Soler C and others (2011) Seminal plasma biochemistry and spermatozoa characteristics of Atlantic cod (Gadus morhua L.) of wild and cultivated origin. Comp Biochem Physiol A 159: $16-24$

> Chambers RC, Waiwood KG (1996) Maternal and seasonal differences in egg sizes and spawning characteristics of captive Atlantic cod, Gadus morhua. Can J Fish Aquat Sci 53:1986-2003

Dallavalle JM (1948) Micromeritics: the technology of fine particles, 2nd edn. Pitman, London

$>$ Dimitriou E, Katselis G, Moutopoulos DK, Akovitiotis C, Koutsikopoulos C (2007) Possible influence of reared gilthead sea bream (Sparus aurata, L.) on wild stocks in the area of the Messolonghi lagoon (Ionian Sea, Greece). Aquacult Res 38:398-408
Ellertsen B, Solemdal P, Sundby S, Tilseth S, Westgard T, Øiestad V (1981) Feeding and vertical distribution of cod larvae in relation to availability of prey organisms. Rapp P-V Reùn Cons Int Explor Mer 178:317-319

$>$ Feindel NJ, Benfey TJ, Trippel EA (2010) Competitive spawning success and fertility of triploid male Atlantic cod Gadus morhua. Aquacult Environ Interact 1:47-55

Feindel NJ, Benfy TJ, Trippel EA (2011) Gonadal development of triploid Atlantic cod Gadus morhua. J Fish Biol 78:1900-1912

Ferguson A, Fleming I, Hindar K, Skaala $\varnothing$, McGinnity $P$, Cross TF, Prodöhl P (2007) Farm escapes. In: Verspoor E, Stradmeyer L, Nielsen JL (eds) The Atlantic salmon: genetics, conservation and management. Blackwell Science, Oxford, p 357-398

Fossum P (1988) A tentative method to estimate mortality in the egg and early fish larval stages, with special reference to cod (Gadus morhua L.). Fisk Dir Skr Havunters 18:329-349

Froese R, Pauly D (2012) Fishbase. Available at www. fishbase.org (version April 2012)

Fuiman LA, Ojanguren AF (2011) Fatty acid content of eggs determines antipredator performance of fish larvae. J Exp Mar Biol Ecol 407:155-165

Glover KA, Quintela M, Wennevik V, Besnier F, Sørvik AGE, Skaala Ø (2012) Three decades of farmed escapees in the wild: a spatio-temporal analysis of Atlantic salmon population genetic structure throughout Norway. PLoS ONE 7:e43129

> Hansen T, Karlsen Ø, Taranger GL, Hemre GI, Holm JC, Kjesbu OS (2001) Growth, gonadal development and spawning time of Atlantic cod (Gadus morhua) reared under different photoperiods. Aquaculture 203:51-67

Hauser L, Carvalho GR (2008) Paradigm shifts in marine fisheries genetics: ugly hypotheses slain by beautiful facts. Fish Fish 9:333-362

> Hindar K, Ryman N, Utter F (1991) Genetic effects of cultured fish on natural fish populations. Can J Fish Aquat Sci 48:945-957

> Hindar K, Fleming IA, McGinnity P, Diserud O (2006) The genetic and ecological effects of salmon farming on wild salmon: modelling from experimental results. ICES J Mar Sci 63:1234-1247

Hutchings JA, Fraser DJ (2008) The nature of fisheries- and farming-induced evolution. Mol Ecol 17:294-313

> Izquierdo MS, Fernandez-Palacios H, Tacon AGJ (2001) Effect of broodstock nutrition on reproductive performance of fish. Aquaculture 197:25-42

Jensen Ø, Dempster T, Thorstad EB, Uglem I, Fredheim A (2010) Escapes of fish from Norwegian sea-cage aquaculture: causes, consequences and prevention escape. Aquacult Environ Interact 1:71-83

> Jørstad KE, van der Meeren T, Paulsen OI, Thomsen T, Thorsen T, Svåsand T (2008) 'Escapes' of eggs from farmed cod spawning in net pens: recruitment to wild stocks. Rev Fish Sci 16:285-295

Julliard R, Stenseth NC, Gjøsæter J, Lekve K, Fromentin JM, Danielssen DS (2001) Natural and fishing mortality in a coastal cod population: a release-recapture experiment. Ecol Appl 11:540-558

Karlsen Ø, Holm JC, Kjesbu OS (1995) Effects of periodic starvation on reproductive investment in first-time spawning Atlantic cod (Gadus morhua L.). Aquaculture 133:159-170

> Karlsen O, Norberg B, Kjesbu OS, Taranger GL (2006) 
Effects of photoperiod and exercise on growth, liver size, and age at puberty in farmed Atlantic cod (Gadus morhua L.). ICES J Mar Sci 63:355-364

Kjesbu OS (1989) The spawning activity of cod, Gadus morhua L. J Fish Biol 34:195-206

Kjesbu OS, Holm JC (1994) Oocyte recruitment in first-time spawning Atlantic cod (Gadus morhua) in relation to feeding regime. Can J Fish Aquat Sci 51:1893-1898

Kjesbu OS, Klungsøyr J, Kryvi H, Witthames PR, Greer Walker M (1991) Fecundity, atresia, and egg size of captive Atlantic cod (Gadus morhua) in relation to proximate body composition. Can J Fish Aquat Sci 48: 2333-2343

Kjesbu OS, Kryvi H, Sundby S, Solemdal P (1992) Buoyancy variations in eggs of Atlantic cod (Gadus morhua L.) in relation to chorion thickness and egg size: theory and observations. J Fish Biol 41:581-599

> Kjesbu OS, Solemdal P, Bratland P, Fonn M (1996) Variation in annual egg production in individual captive Atlantic cod (Gadus morhua). Can J Fish Aquat Sci 53:610-620

Kjesbu OS, Witthames PR, Solemdal P, Greer Walker M (1998) Temporal variations in the fecundity of ArctoNorwegian cod (Gadus morhua) in response to natural changes in food and temperature. J Sea Res 40:303-321

> Kjesbu OS, Righton D, Krüger-Johnsen M, Thorsen A, Michalsen K, Fonn M, Witthames PR (2010) Thermal dynamics of ovarian maturation in Atlantic cod (Gadus morhua). Can J Fish Aquat Sci 67:605-625

Kjørsvik E, Mangor Jensen A, Holmefjord I (1990) Egg quality in fishes. Adv Mar Biol 26:71-113

Kjørsvik E, Olsen C, Wold PA, Hoehne-Reitan K and others (2009) Comparison of dietary phospholipids and neutral lipids on skeletal development and fatty acid composition in Atlantic cod (Gadus morhua). Aquaculture 294: $246-255$

> Knutsen T, Melle W, Calise L (2001) Determining the mass density of marine copepods and their eggs with a critical focus on some of the previously used methods. J Plankton Res 23:859-873

Knutsen H, Olsen EM, Jorde PE, Espeland SH, Andre C, Stenseth NC (2011) Are low but statistically significant levels of genetic differentiation in marine fishes 'biologically meaningful'? A case study of coastal Atlantic cod. Mol Ecol 20:768-783

Kristiansen TS, Jørstad KE, Otterå H, Paulsen OI, Svåsand T (1997) Estimates of larval survival of cod by releases of genetically marked yolk-sac larvae. J Fish Biol 51: 264-283

Kristiansen TS, Otterå H, Svåsand T (2000) Size-dependent mortality of juvenile Atlantic cod, estimated from recaptures of released reared cod and tagged wild cod. J Fish Biol 56:687-712

Lanes CFC, Bizuayehu TT, Bolla S, Martins C and others (2012) Biochemical composition and performance of Atlantic cod (Gadus morhua L.) eggs and larvae obtained from farmed and wild broodstock. Aquaculture 324-325: 267-275

> Larsen LH, Pedersen T (2002) Migration, growth and mortality of released reared and wild cod (Gadus morhua L.) in Malangen, northern Norway. Sarsia 87:97-109

> Moe H, Dempster T, Sunde LM, Winther U, Fredheim A (2007) Technological solutions and operational measures to prevent escapes of Atlantic Cod (Gadus morhua) from sea-cages. Aquacult Res 38:91-99

- Naylor R, Hindar K, Fleming IA, Goldburg R and others
(2005) Fugitive salmon: assessing the risks of escaped fish from net-pen aquaculture. Bioscience 55:427-437

> Otterå H, Agnalt AL, Jørstad KE (2006) Differences in spawning time of captive Atlantic cod from four regions of Norway, kept under identical conditions. ICES J Mar Sci 63:216-223

Pavlov D, Kjørsvik E, Refsti T, Andersen O (2004) Broodstock and egg production. In: Moksness E, Kjorsvik E, Olsen Y (eds) Culture of cold water marine fish. Blackwell Publishing, Oxford

Pedersen T, Pope JG (2003) Sampling and a mortality model of a Norwegian fjord cod (Gadus morhua L.) population. Fish Res 63:1-20

Pepin P, Myers RA (1991) Significance of egg and larval size to recruitment variability of temperate marine fish. Can J Fish Aquat Sci 48:1820-1828

> Pickova J, Mørkøre T (2007) Alternate oils in fish feeds. Eur J Lipid Sci Technol 109:256-263

Pickova J, Dutta PC, Larson PO, Kiessling A (1997) Early embryonic cleavage pattern, hatching success and egglipid fatty acids composition: comparison between two cod stocks. Can J Fish Aquat Sci 54:2410-2416

Salvanes AGV, Ulltang O (1992) Population parameters, migration and exploitation of the cod (Gadus morhua L.) in Masfjorden, western Norway. Fish Res 15:253-289

Salze G, Tocher DR, Roy WJ, Robertson DA (2005) Egg quality determinants in cod (Gadus morhua L.): egg performance and lipids in eggs from farmed and wild broodstock. Aquacult Res 36:1488-1499

Sargent JR, Bell MV, Bell JG, Henderson RJ, Tocher DR (1995) Origins and functions of (n-3) polyunsaturated fatty acids in marine organisms. In: Cevc G, Paltauf F (eds) Phospholipids: characterization, metabolism and novel biological applications. AOCS Press, Champaign, IL, p 248-259

Sargent JR, Bell JG, McEvoy L, Tocher DR, Estevez A (1999a) Recent developments in the essential fatty acid nutrition of fish. Aquaculture 177:191-200

Sargent JR, McEvoy L, Estevez A, Bell JG, Bell MV, Henderson RJ, Tocher DR (1999b) Lipid nutrition of marine fish during early development: current status and future directions. Aquaculture 179:217-229

Sargent JR, Tocher DR, Bell JG (2002) The lipids. In: Halver JE, Hardy RW (eds) Fish nutrition, 3rd edn. Academic Press, San Diego, CA, p 181-257

Skaala Ø, Wennevik V, Glover KA (2006) Evidence of temporal genetic change in wild Atlantic salmon, Salmo salar L., populations affected by farm escapees. ICES J Mar Sci 63:1224-1233

Skjæraasen JA, Mayer I, Meager JJ, Rudolfsen G, Karlsen O, Haugland T, Kleven O (2009) Sperm characteristics and competitive ability in farmed and wild cod. Mar Ecol Prog Ser 375:219-228

Skjæraasen JE, Meager JJ, Karlsen O, Hutchings JA, Ferno A (2011) Extreme spawning-site fidelity in Atlantic cod. ICES J Mar Sci 68:1472-1477

Slagstad D, McClimans TA (2005) Modeling the ecosystem dynamics of the Barents Sea including the marginal ice zone: I. Physical and chemical oceanography. J Mar Syst 58:1-18

Solemdal P, Bergh Ø, Dahle G, Falk-Petersen IB and others (1993) Size of spawning Arcto-Norwegian cod (Gadus morhua L.) and the effects on their eggs and early larvae. ICES CM 1993/G:41

Sundby S (1997) Turbulence and ichthyoplankton: influence 
on vertical distribution and encounter rates. Sci Mar 61: $159-176$

Sundby S (2000) Recruitment of Atlantic cod stocks in relation to temperature and advection of copepod populations. Sarsia 85:277-298

Sundby S, Bjørke H, Soldal AV, Olsen S (1989). Mortality rates during the early life stages and year-class strength of northeast Arctic cod (Gadus morhua L.). Rapp Cons Int Explor Mer 191:351-358

Sundnes G, Leivestad H, Iversen O (1965) Buoyancy determination of eggs from the cod (Gadus morhua L.). J Cons Int Explor Mer 29(3):249-252

Svåsand T, Jørstad KE, Otterå H, Kjesbu OS (1996) Differences in growth performance between Arcto-Norwegian and Norwegian coastal cod reared under identical conditions. J Fish Biol 49:108-119

Taggart CT, Frank KT (1990) Perspectives on larval fish ecology and recruitment processes. Probing the scales of relationships. In: Sherman K, Alexander LM, Gold BD (eds) Large marine ecosystems. American Association for the Advancement of Science, Washington, DC, p 151-164

Tandler A, Harel M, Koven WM, Kolkovski S (1995) Broodstock and larvae nutrition in gilthead seabream Sparus aurata, new findings on its mode of involvement in improving growth, survival and swimbladder inflation. Isr J Aquac Bamidgeh 47:95-111

Taranger GL, Aardal L, Hansen T, Kjesbu OS (2006) Continuous light delays sexual maturation and increases growth of Atlantic cod (Gadus morhua L.) in sea cages. ICES J Mar Sci 63:365-375

Taranger GL, Carrillo M, Schulz RW, Fontaine P and others (2010) Control of puberty in farmed fish. Gen Comp Endocrinol 165:483-515

Thorsen A, Kjesbu OS (2001) A rapid method for the estima-

Editorial responsibility: Marianne Holmer,

Odense, Denmark tion of oocyte size and potential fecundity in Atlantic cod using computer-aided particle analysis system. J Sea Res 46:295-308

Tocher DR (2010) Fatty acid requirements in ontogeny of marine and freshwater fish. Aquacult Res 41:717-732

Triantafyllidis A, Karaiskou N, Bonhomme F, Colombo L and others (2007) Management options to reduce genetic impacts of aquaculture activities. In: Svåsand T, Crosetti D, García-Vázquez E, Verspoor E (eds) Genetic impact of aquaculture activities on native populations. GenImpact Compendium. Available at http://genimpact.imr.no/ compendium

Trippel EA, Benfey TJ, Neil SRE, Cross N, Blanchard MJ, Powell F (2008) Effects of continuous light and triploidy on growth and sexual maturation in Atlantic cod, Gadus morhua. Cybium 32:136-138

Turchini GM, Torstensen BE (2009) Fish oil replacement in finfish nutrition. Rev Aquac 1:10-57

Uglem I, Berg M, Varne R, Nilsen R, Mork J, Bjørn PA (2011) Discrimination of wild and farmed Atlantic cod (Gadus morhua L.) on basis scale circuli pattern and body morphology. ICES J Mar Sci 68:1928-1936

van der Meeren T, Jørstad KE, Paulsen OI, Dahle G (2012) Offspring from farmed cod (Gadus morhua L.) spawning in net pens: documentation of larval survival, recruitment to spawning stock, and successful reproduction. ICES CM 2012/P:11

> Wright PJ, Galley E, Gibb IM, Neat FC (2006) Fidelity of adult cod to spawning grounds in Scottish waters. Fish Res 77:148-158

Wroblewski JS, Hiscock HW, Bradbury IR (1999) Fecundity of Atlantic cod (Gadus morhua) farmed for stock enhancement in Newfoundland bays. Aquaculture 171: 163-180

Submitted: April 12, 2012; Accepted: October 1, 2012 Proofs received from author(s): November 8, 2012 